\author{
${ }^{1}$ Nasim Pourebrahim ${ }^{\text {iD }, ~}{ }^{1}$ Amirhussein Elhamirad ${ }^{\text {iD }}$, \\ ${ }^{2 *}$ Soodabeh Einafshar ${ }^{\text {iD }, ~}{ }^{1}$ Mohammad Armin \\ ${ }^{1}$ Sabzevar Branch (IAUS) Islamic Azad University, Sabzevar Branch (IAUS) \\ Sabzevar Khorasan Razavi, Iran. \\ ${ }^{2}$ Department of Agricultural Engineering Institute, Khorasan Razavi Agricultural and \\ Natural Resources Research and Education Center, AREEO, Mashhad, Iran, \\ e-mail: soodabeheyn@yahoo.com

\section{Thin layer drying models, antioxidative activity and phenolic compounds of rose petals (Rosa damascena Mill.) in tray dryer}

\begin{abstract}
The drying behavior of the Damask rose (Rosa damascena Mill.) petals in a thin layer hot air drying at 35,45 and $55^{\circ} \mathrm{C}$ and $0.4,1.2$ and $2\left(\mathrm{~m} \cdot \mathrm{s}^{-1}\right)$ air velocity levels, was investigated. The Midilli was the most suitable model among 14 different thin-layer models for showing the thin-layer drying characteristics. At the experimental temperature $\left(35-55^{\circ} \mathrm{C}\right)$ and air velocity levels $\left(0.4,1.2\right.$ and $\left.2 \mathrm{~m} \cdot \mathrm{s}^{-1}\right)$ the effective moisture diffusivity was $2.02 \times 10^{-12}-11.3 \times 10^{-12}\left(\mathrm{~m}^{2} \cdot \mathrm{s}^{-1}\right)$ and the activation energy varied from 56.3 to $64.5\left(\mathrm{~kJ} \cdot \mathrm{mol}^{-1}\right)$. Total anthocyanin content (TAC) ranged $77-240\left(\mathrm{mg} \cdot \mathrm{L}^{-1}\right)$. The rose petal extracts showed higher DPPH (59.51\%) and lower FRAP $\left(1213.24 \mu \mathrm{mol}\left(\mathrm{Fe}^{+2}\right) \cdot \mathrm{L}^{-1}\right)$, at an increasing temperature from 35 to $55^{\circ} \mathrm{C}$. Results showed that the higher temperature caused less TAC. At $45-55^{\circ} \mathrm{C}$ and air velocities $0.4-1.2\left(\mathrm{~m} \cdot \mathrm{s}^{-1}\right)$ the number of anthocyanins increased significantly, but at air velocities, 1.2- $2\left(\mathrm{~m} \cdot \mathrm{s}^{-1}\right)$ a decrease was observed.
\end{abstract}

Key words: Rosa Damascena Mill., Thin layer dryer, Anthocyanin, Phenolic compounds, Antioxidative power.

\section{Introduction}

Damask rose (Rosa damascena Mill.) is an ornamental plant from the family Rosaceae with more than 200 species and approximately 18000 cultivars. Damask rose is widely cultivated in Iran, Turkey, Bulgaria, India, Morocco, France, China, Italy, Libya, South Russia and the Ukraine. It is used for producing rose oil, water, concrete (rose oil solid), and absolute, which are significant base materials for the medicine, food products, and cosmetic industry [1]. Some factors like genotype of Damask rose, environment conditions, the time of harvesting, and the technology of processing and distillation, substantially affect the amount, percentage and compounds of rose essential oil and extract [2]. Numerous compounds can be extracted from pistil, ovary and sepal of Rose flower such as flavonoids, glycosides, terpenes and anthocyanins. Studies shows that Damask rose and rosehip seed oils are significantly rich in unsaturated fatty acids (omega fatty acid), bitter principle, organic acids and tanning matter [3]. Dried flowers are also used as flavor and laxative agents [1].
The short harvest duration (40 days) of Rose flower and its high moisture make the transportation and storage a difficult task [4]. The destruction of high fresh petals occurs at high speed rates due to the growth of the living organisms such as bacteria, molds and yeasts. Therefore, drying at the appropriate moisture content is an important step in the process [5]. Drying rose petals would introduce new utilization opportunities such as decorative, herbal, aromatic, hydrotherapeutic and cosmetic uses. In addition, with an increased demand for using the roses in health and aroma therapy, the importance of preserving color, flavor, and essential oils during the drying process has been identified [6].

Drying method is one of the oldest processes for product preservation and protection. This technique decreases humidity from $\sim 85 \%$ wb to $\sim \% 8-12 \mathrm{wb}$. The drying process should be completed in a short period of time to prevent the decomposition and minimize the used energy for the business concerns [7]. The most common commercial technique of drying food and chemical products is air drying. Hot air drying in food processing decreases the drying 
time and hence maintains the dried product quality [8]. Therefore, the temperature and humidity levels of drying air, drying speed, and drying duration should be optimized to achieve the highest product quality [9].

Thermal and physical characteristics such as heat and mass transfer, moisture diffusion, activation energy, and energy consumption are essential in the design of agricultural crops dryers [10]. The drying process and apparatus modeling are substantially important in order to optimize the operation parameters and improve the performance of the drying system. Thin layer drying removes the moisture from a porous material by evaporation, in which drying air is passed through a thin layer of the material until it reaches a moisture balance. The external factors of the process, the type and size of the product, and the internal diffusion mechanisms control the drying rate [11].

Economic justification, quality, and quantity of the dried petals are dependent on the proper drying methods. Therefore, designing an effective operating system to minimize the drying process time and optimize energy consumption is required. The objectives of this paper are to 1) investigate the drying behavior of Damask rose petals through thinlayer drying 2) determine the best mathematical model for describing the drying process kinetics and 3) evaluate the effects of hot air velocity and temperature on qualitative properties of petals.

\section{Materials and methods}

\section{Sample Preparation}

Fresh rose flowers were picked up early in the morning, April to May 2018, from Gonabad, Khorasan Razavi province, Iran. Samples were transported to the laboratory and petals were separated before drying.

\section{Chemicals}

The applied chemicals and solvents were analytical reagent grade and were supplied by Merck (Darmstadt, Germany) and Sigma-Aldrich (St. Louis, MO) Chemical Companies.

\section{Experimental Design}

A laboratory-model tray dryer, equipped with installed instrumentations was used for the drying test. Different parts of dryer were air inlet and outlet parts, control unit and drying chamber (in which perforated trays are placed horizontally). The specifications of the fabricated dryer along with instrumentations are all explained in detail in [12]. Before the start of the drying process, the desirable constant temperature was obtained by the electrical heaters. To execute a drying run at each temperature, the dryer turned on 30 minutes so that it would stabilize at the specified temperature and air velocity [12]. About $10 \mathrm{~g}$ of fresh petals were spread on the shelves as a thin layer and kept in the drying chamber. Drying experiments were conducted at the temperature of 35,45 and $55^{\circ} \mathrm{C}$ and hot air velocities of $0.4,1.2$ and $2 \mathrm{~m} \cdot \mathrm{s}^{-1}$. The reduced moisture content of petals was recorded every 2 minutes to achieve a constant weight and obtain the drying curves.

\section{Mathematical modeling}

Moisture ratio (MR) of the petal samples was obtained using equation (1):

$$
M R-\left(M_{t}-M_{t e}\right) F\left(M_{0}-M_{\tau}\right)
$$

where, $\mathrm{M}_{\mathrm{t}}$ is the last moisture content, $\mathrm{M}_{0}$ is the initial moisture content, and $\mathrm{M}_{\mathrm{e}}$ is the equilibrium moisture content. In practice, $\mathrm{M}_{\mathrm{e}}$ value is rather less than $\mathrm{M}_{\mathrm{t}}$ or $\mathrm{M}_{0}$. Thus, the equation can be simplified as follows [13]:

$$
M R=M_{1} / M_{0}
$$

Moisture ratio data were consistent with 14 thin-layer models that were mainly used to assess their suitability for thin layer drying kinetics of foods. MATLAB R2013 tool was used to fit the experimental data to the 14 thin-layer models. Three statistical parameters including coefficient of determination $\left(\mathrm{R}^{2}\right)$, root mean squares error (RMSE), and sum square error (SSE) were used to determine the performance of the models. For quality fit, $\mathrm{R}^{2}$ value should be closed to one while SSE and RMSE values should be closed to zero.

\section{Moisture Loss Kinetics}

Fick's second law of unsteady state diffusion can describe the transport of moisture during the drying process that occurs in the falling rate period for most food materials [14]. It is calculated using the equation (3):

$$
\frac{\sigma M}{\partial t}=D_{E f f^{2}} \nabla^{2}
$$

where, $D_{\text {eff }}$ is effective moisture diffusion $\left(\mathrm{m}^{2} \mathrm{~s}^{-1}\right)$ and $\mathrm{M}$ is moisture content

Research shows that $D_{\text {eff }}$ is related to temperature and the kind of material being dried, including its texture and structure [15]. For 
sufficiently long period of drying, using the first term in the series in the equation is significant and therefore [16]:

$$
M R=\frac{a}{\pi^{2}} \exp \left[\frac{-D_{g t \pi^{2} \pi^{2} t}}{4 E^{2}}\right]
$$

Taking the natural logarithm of the equation gives:

$$
\ln (M R)=\ln \left(\frac{8}{\pi^{2}}\right)-\frac{\pi^{2} D_{e f f} t}{4 L^{2}}
$$

where, $\mathrm{L}$ is the half thickness of Rosa damascena petal (RDP). Hence, the effective moisture diffusivity $\left(D_{\text {eff }}\right)$ is obtained by plotting the experimental drying data in terms of $\ln (\mathrm{MR})$ against drying time (s).

Energy of activation $\left(E_{a}\right)$ in a sample is the minimum amount of energy required for the initiation of a drying process to cause moisture diffusion through the sample. Therefore, the activation energy was calculated using Arrhenius equation [10] as shown in Eq. (6):

$$
D_{* f f}=D_{0 . \exp }\left(-\frac{E_{a}}{R_{g} T_{a b s}}\right)
$$

$\mathrm{E}_{\mathrm{a}}$ : the energy of activation, $\mathrm{D}_{0}$ : the preexponential factor of Arrhenius equation $\left(\mathrm{m}^{2} \mathrm{~s}^{-1}\right)$, $\mathrm{R}_{\mathrm{g}}$ : the universal gas constant $\left(8.3143 \mathrm{~kJ} \cdot \mathrm{mol}^{-1} \cdot \mathrm{K}^{-1}\right)$, and $\mathrm{T}_{\mathrm{abs}}$ : the absolute air temperature $\left({ }^{\circ} \mathrm{K}\right) \cdot \mathrm{D}_{0}$ and the corresponding $\mathrm{E}_{\mathrm{a}}$ were determined by plotting $\ln \left(D_{\text {eff }}\right)$ versus $1 / T[14]$.

\section{Total Anthocyanin Content}

Anthocyanin pigments undergo reversible structural transformations with a change in $\mathrm{pH}$ manifested by strikingly different absorbance spectra. The colored oxonium form predominates at $\mathrm{pH} 1.0$ and the colorless hemiketal form at $\mathrm{pH} 4.5$. The pH-differential method is based on this reaction, and permits accurate and rapid measurement of the total anthocyanins, even in the presence of polymerized degraded pigments and other interfering compounds. Briefly, transfer $1 \mathrm{~mL}$ extracted solution into $10 \mathrm{~mL}$ volumetric flask for preparing two dilutions of the sample, one adjust volume with potassium chloride buffer, $\mathrm{pH} 1.0$, and the other with sodium acetate buffer, $\mathrm{pH}$ 4.5, diluting each. Let these dilutions equilibrate for 15 min. Measure the absorbance of each dilution at the 510 and $700 \mathrm{~nm}$ (to correct for haze), against a blank cell filled with distilled water [17]. TAC was expressed as cyanidin-3-glucoside $(\% \mathrm{w} / \mathrm{w})$

Int. j. biol. chem. (Online) equivalents and measured by the following equation (7):

Total anthocyanin content

$$
\left(\% W / W^{2}\right)=\frac{A}{\times l} \times M W \times D F \times \frac{V}{W} \times 100 \%
$$

where,

$$
A=\left(A_{620 \mathrm{~mm}}-A_{700_{\mathrm{mm}}}\right)_{P H 10}-\left(A_{\mathrm{B} 20 \mathrm{~mm}}-A_{70 \mathrm{~mm}}\right)_{P H 46}
$$

MW (molecular weight): 449.2 for cyanidin-3glucoside; DF: dilution factor; W: sample weight $(\mathrm{mg})$; 1: diameter of spectrophotometer cell $(\mathrm{cm}) ; \varepsilon$ : 26,900 M extinction coefficient in $\mathrm{L} \cdot \mathrm{mol}^{-1} \cdot \mathrm{cm}^{-1}$ for cyd-3-glu; and $10^{3}$ : factor for conversion from $g$ to mg.

Determination of Antioxidant Activity

DPPH and FRAP assays were used to evaluate the total antioxidant activity.

The DPPH method: The radical scavenging activity of RPE (Rose petals extract) was tested according to the method described in [18]. RPE was mixed with $1 \mathrm{ml}$ of $0.5 \mathrm{mM}$ free radical 2, 2diphenyl-1-picrylhydrazyl (DPPH) methanolic solution, stored in the dark for $30 \mathrm{~min}$, and then the absorbance was measured at $517 \mathrm{~nm}$. The radical scavenging activity (\%RSA) of RPE was calculated by the following equation:

$$
\% \text { RSA }=\frac{A_{\text {gontrol }}-A_{\text {gampir }}}{A_{\text {control }}} \times 100
$$

where $\mathrm{A}_{\text {sample }}$ is the absorbance of RPE at a particular level and $\mathrm{A}_{\text {control }}$ is the absorbance of the DPPH solution.

The FRAP method: The FRAP (Ferric reducingantioxidant power) assay was performed by the 2,4 , and 6-Tripyridyl-S-triazine (TPTZ) following the method of Benzie and Strain [19]. FRAP reagent was prepared by mixing acetate buffer $(0.3 \mathrm{M}$, $\mathrm{pH}=3.6)$, TPTZ solution $(10 \mathrm{mM})$ and $\mathrm{FeCl}_{3}(20$ $\mathrm{mM})$ in the ratio of 10:1:1. Briefly, $90 \mu \mathrm{RPE}(10 \mathrm{gr}$ $\left.\mathrm{L}^{-1}\right), 2700 \mu \mathrm{l}$ of freshly prepared FRAP reagent and $270 \mu \mathrm{l}$ distilled water were mixed and warmed to $37^{\circ} \mathrm{C}$ in a water bath and absorptions were determined at $595 \mathrm{~nm}$. A standard curve was prepared using different concentrations of (200$2000 \mathrm{Fe}$ (II) $\mu \mathrm{mol} \cdot \mathrm{L}^{-1}$ ).

Total phenolic content (TPC) determination

The total phenolic content was determined espectrophotometrically using the Folin Ciocalteu reagent described by Singleton and Rossi [20]. The calibration curve was plotted by absorbance measurements of various concentrations of Gallic acid $\left(0.04-0.4 \mathrm{mg} \cdot \mathrm{ml}^{-1}\right)$ at $760 \mathrm{~nm}$. 


\section{Results and discussion}

\section{Drying Model Investigation}

The Model constants, $\mathrm{R}^{2}$, RMSE, and SSE for
14 thin layer drying models (at three different drying temperatures with three levels of hot air velocities) consistent with the moisture ratio are presented in Table 1.

Table 1 - Coefficient of determination range for some thin-layer drying models applied to Rosa damascena petals (RDP)

\begin{tabular}{|c|c|c|c|c|c|c|c|c|c|c|c|c|}
\hline \multirow{3}{*}{$\begin{array}{c}\mathbf{T}\left({ }^{\circ} \mathbf{C}\right) \\
35\end{array}$} & \multirow{3}{*}{\begin{tabular}{|c|c|}
$\mathbf{V}$ \\
$\left(\mathbf{m} \cdot \mathbf{s}^{-\mathbf{1}}\right)$
\end{tabular}} & \multirow{3}{*}{$\begin{array}{l}\begin{array}{c}\text { Model } \\
\text { name }\end{array} \\
\text { Midilli }\end{array}$} & \multirow{3}{*}{$\begin{array}{c}\text { Model equation } \\
M R=a \exp \left(-\mathrm{kt}^{\mathrm{n}}\right)+\mathrm{b} 1\end{array}$} & \multirow{2}{*}{\multicolumn{6}{|c|}{$\begin{array}{c}\text { Coefficients } \\
\text { a b c d h g k n }\end{array}$}} & \multirow{3}{*}{$\begin{array}{c}\mathbf{R}^{2} \\
0.999\end{array}$} & \multirow{3}{*}{$\begin{array}{c}\mathbf{X}^{2} \\
0.00003\end{array}$} & \multirow{3}{*}{$\begin{array}{l}\text { RMSE } \\
0.00522\end{array}$} \\
\hline & & & & & & & & & & & & \\
\hline & & & & 0.9836 & -0.00104 & & & 0.0062 & 1.24 & & & \\
\hline 45 & 0.4 & Midilli & $\mathrm{MR}=\mathrm{a} \exp \left(-\mathrm{kt}^{\mathrm{n}}\right)+\mathrm{b} 1$ & 0.9727 & -0.00085 & & & 0.0185 & 1.256 & 0.999 & 0.00007 & 0.00780 \\
\hline 55 & 0.4 & Two term & $\begin{array}{c}\mathrm{MR}=\mathrm{a} \exp (-\mathrm{bt})+\mathrm{c} \exp \\
(-\mathrm{dt})\end{array}$ & -14.02 & 0.1611 & 15.01 & 0.1544 & & & 0.999 & 0.00004 & 0.00585 \\
\hline 35 & 1.2 & Midilli & $\mathrm{MR}=\mathrm{a} \exp \left(-\mathrm{kt}^{\mathrm{n}}\right)+\mathrm{k} 1$ & 0.9277 & -0.00005 & & & 0.0012 & 1.733 & 0.995 & 0.00053 & 0.02218 \\
\hline 45 & 1.2 & Midilli & $\mathrm{MR}=\mathrm{a} \exp \left(-\mathrm{kt}^{\mathrm{n}}\right)+\mathrm{b}_{1}$ & 0.9777 & -0.00056 & & & 0.0320 & 1.146 & 0.999 & 0.00010 & 0.00946 \\
\hline 55 & 1.2 & Midilli & $\mathrm{MR}=\mathrm{a} \exp \left(-\mathrm{kt}^{\mathrm{n}}\right)+\mathrm{bt}$ & 0.9815 & -0.00034 & & & 0.0428 & 1.33 & 0.998 & 0.00018 & 0.01208 \\
\hline 35 & 2 & Midilli & $\mathrm{MR}=\mathrm{a} \exp \left(-\mathrm{kt}^{\mathrm{n}}\right)+\mathrm{b} 1$ & 0.9598 & -0.00085 & & & 0.0043 & 1.315 & 0.999 & 0.00012 & 0.01056 \\
\hline 45 & 2 & Two term & $\begin{array}{c}M R=a \exp (-b t)+c \exp \\
(-d t)\end{array}$ & -17.74 & 0.1111 & 18.73 & 0.1073 & 0.0645 & & 0.999 & 0.00005 & 0.00654 \\
\hline 55 & 2 & Jena\&Das & $\mathrm{MR}=\mathrm{a} \exp (-\mathrm{kt}+\mathrm{a})+\varepsilon$ & $\begin{array}{c}- \\
0.1729\end{array}$ & 0.6838 & 1.176 & & & & 0.999 & 0.00005 & 0.00606 \\
\hline
\end{tabular}

$\mathrm{R}^{2}$, RMSE and SSE values varied from 0.995 to $0.999,0.00522$ to 0.02218 , and 0.0006 to 0.0246 , respectively. Compared to other models, Midilli drying model had the highest $\mathrm{R}^{2}$ and the minimum RMSE and SSE values, at $35^{\circ} \mathrm{C}$ air temperature and $0.4\left(\mathrm{~m} \cdot \mathrm{s}^{-1}\right)$ while the two term model had the best performance for air velocity of $0.4 \mathrm{~m} \cdot \mathrm{s}^{-1}$ at $55^{\circ} \mathrm{C}$ and $2 \mathrm{~m} \cdot \mathrm{s}^{-1}$ at $45^{\circ} \mathrm{C}$. Jena \& Das was the best model for air velocity of $2 \mathrm{~m} \cdot \mathrm{s}^{-1}$ at $55{ }^{\circ} \mathrm{C}$. For all the nine drying conditions, the Midilli was the most suitable model to show the thin-layer drying characteristics of the petals. Similar results were reported for Rosa damascena petals drying by Karimi and Bankar [21]. The Midilli model has been also successfully used to study the drying characteristics of agricultural products such as savory leaves and eggplant [22].

Effective Moisture Diffusivity and Activation Energy

Effective moisture diffusivity is influenced by temperature, air velocity and the kind of substance. The higher temperature and air velocity cause the shorter drying time due to increased thermal

Int. j. biol. chem. (Online) gradients and mass transfer and as a result, drying rate increases [23]. The values of temperature, air velocity and effective moisture diffusivity are showed in Table 2.

Table 2 - Variations effective moisture diffusivity at different temperatures and hot air velocities

\begin{tabular}{|c|c|c|c|}
\hline $\begin{array}{c}\text { Temperature } \\
\left({ }^{\circ} \mathrm{C}\right)\end{array}$ & $\begin{array}{c}\text { Hot air } \\
\text { velocity }\left(\mathrm{m} \cdot \mathrm{s}^{-1}\right)\end{array}$ & $\mathbf{R}^{2}$ & $D_{\text {eff }}\left(m^{2} s^{-1}\right)$ \\
\hline 35 & \multirow{3}{*}{0.4} & 0.95 & $2.2 \times 10^{-12}$ \\
\hline 45 & & 0.96 & $4.85 \times 10^{-12}$ \\
\hline 55 & & 0.99 & $7.68 \times 10^{-12}$ \\
\hline 35 & \multirow{3}{*}{1.2} & 0.97 & $2.42 \times 10^{-12}$ \\
\hline 45 & & 0.98 & $4.9 \times 10^{-12}$ \\
\hline 55 & & 0.98 & $11.3 \times 10^{-12}$ \\
\hline 35 & \multirow{3}{*}{2} & 0.94 & $2.02 \times 10^{-12}$ \\
\hline 45 & & 0.99 & $5.25 \times 10^{-12}$ \\
\hline 55 & & 0.98 & $9.29 \times 10^{-12}$ \\
\hline
\end{tabular}


An increase in the temperature at constant air velocity increased the effective moisture diffusivity. Moisture diffusivity for the petals showed a minimum value of $2.02 \times 10^{-12} \mathrm{~m}^{2} \cdot \mathrm{s}^{-1}$ at $35^{\circ} \mathrm{C}$ for air velocity of $2 \mathrm{~m} \cdot \mathrm{s}^{-1}$ and a maximum value of $11.3 \times 10^{-12} \mathrm{~m}^{2} \cdot \mathrm{s}^{-1}$ at air velocity of $1.2 \mathrm{~m} \cdot \mathrm{s}^{-1}$ and $55^{\circ} \mathrm{C}$. The results demonstrate that at a constant air velocity, the higher temperature caused the more effective moisture diffusivity. The most effective moisture diffusivity was observed at $55^{\circ} \mathrm{C}$. Similarly, Sharayei et al. [24] found that the maximum value of effective moisture diffusivity is at the highest temperature.

Drying temperature affects the internal mass transfer during drying, and ultimately the moisture diffusivity [14]. This is due to a higher heating energy that increases the water molecules' activities and leads to a higher moisture diffusivity when samples are dried. Also, lower energy is required to remove the moisture at higher temperature because the water molecules are lightly bound to the food complex [25].

The Arrhenius equation was calculated for the activation energy $\left(E_{a}\right)$ of air velocity values $(9)$ :

$$
D_{e}=D_{0 \cdot \operatorname{sex}}\left(-\frac{E_{\alpha}}{R T}\right)
$$

$\mathrm{E}_{\mathrm{a}}$ : The energy of activation $\left(\mathrm{kJ} \cdot \mathrm{mol}^{-1}\right), \mathrm{R}$ : universal gas constant $\left(8.3143 \mathrm{~kJ} \cdot \mathrm{mol}^{-1}\right)$, $\mathrm{T}$ : absolute air temperature $\left({ }^{\circ} \mathrm{K}\right), \mathrm{D}_{0}$ : The pre-exponential factor of the Arrhenius equation $\left(\mathrm{m}^{2} \cdot \mathrm{s}^{-1}\right)$.

Figure 1 shows the plot of $\operatorname{Ln}\left(\mathrm{D}_{\text {eff }}\right)$ versus $1 / \mathrm{T}$ at various treatments.
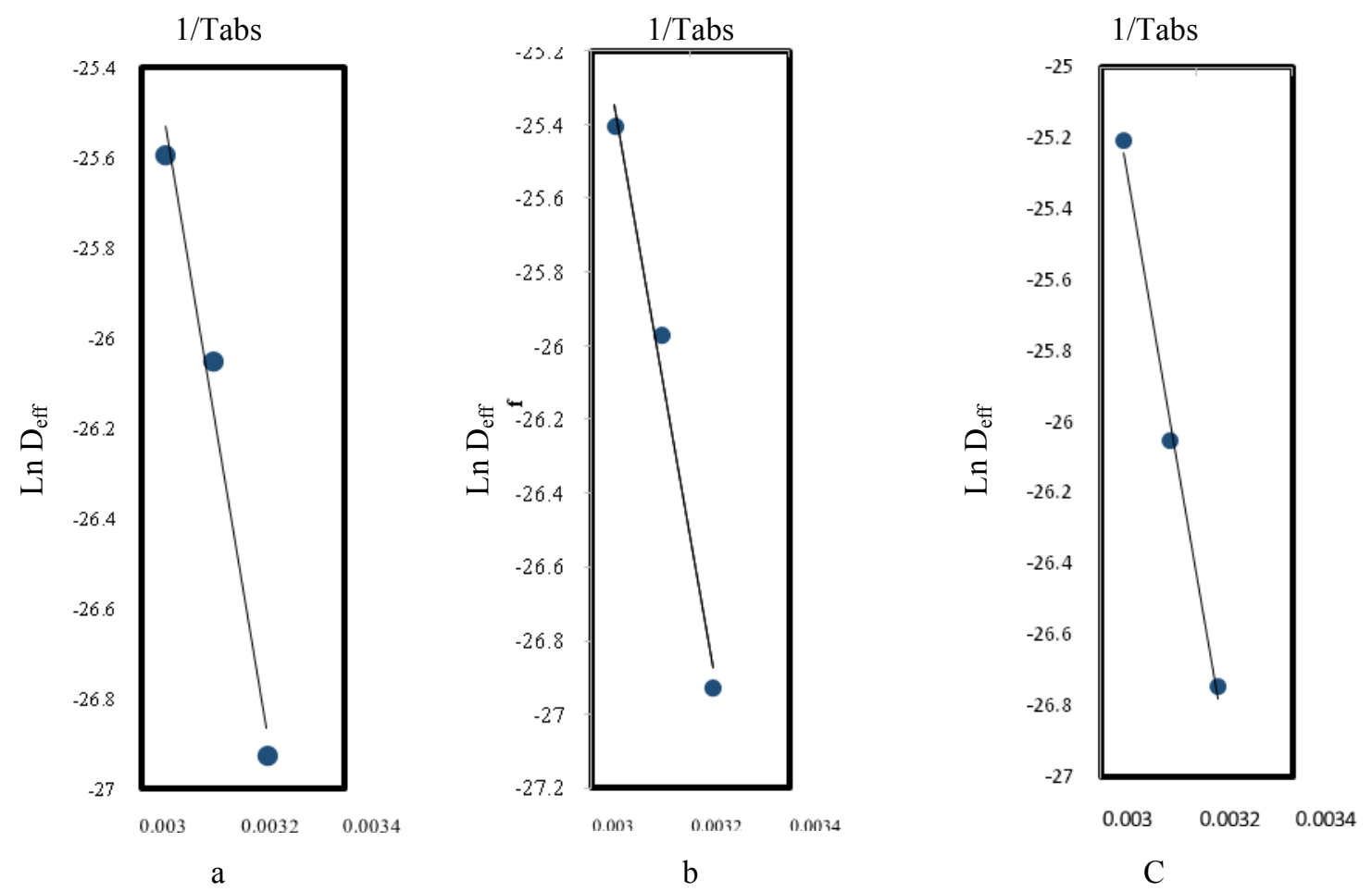

Figure 1 - Plotting experimental data for measuring of $E_{\mathrm{a}}: \mathrm{a}: 0.4 \mathrm{~m} \cdot \mathrm{s}^{-1}, \mathrm{~b}: 2 \mathrm{~m} \cdot \mathrm{s}^{-1} \mathrm{c}: 1.2 \mathrm{~m} \cdot \mathrm{s}^{-1}$ 


$$
\ln D_{e}=\ln D_{0}-\frac{E_{q}}{B T}
$$

The slope of the line (equation 10) was used for the calculation of the Activation energy $\left(E_{a}\right)$ as follows

$$
E_{a}=-(\text { stope } x R)
$$

In this study, the values of $E_{a}$ were in the ranges of 56.3 to $64.5 \mathrm{~kJ} \cdot \mathrm{mol}^{-1}$, a result also reported by Sharayei et al. [24] for saffron petals. Aghbashlo et al. [10] and Doymaz [16] reported Ea of barberry and tomato varied from 110.837 to 130.61 and 17.40 to $32.94 \mathrm{~kJ} \cdot \mathrm{mol}^{-1}$, respectively.

Values of $\mathrm{E}_{\mathrm{a}}$ and $\mathrm{D}_{0}$ at air velocity are represented in Table 3. The maximum and minimum values of $\mathrm{E}_{\mathrm{a}}\left(64.5 \mathrm{~kJ} \cdot \mathrm{mol}^{-1}\right.$ and $\left.56.3 \mathrm{~kJ} \cdot \mathrm{mol}^{-1}\right)$ were at air velocity of 1.2 and $0.4\left(\mathrm{~m} \cdot \mathrm{s}^{-1}\right)$, respectively.
Table $3-E_{a}$ and $D_{0}$ at different hot air velocities

\begin{tabular}{|c|c|c|}
\hline $\begin{array}{c}\text { Hot air velocity } \\
\left(\mathbf{m . s}^{-\mathbf{1}}\right)\end{array}$ & $\mathbf{E}_{\mathbf{a}}\left(\mathbf{K J ~ m o l}^{\mathbf{1}}\right)$ & $\mathbf{D}_{\mathbf{0}}$ \\
\hline 0.4 & 56.3 & $7.5 \times 10^{-8}$ \\
\hline 1.2 & 64.5 & $2.2 \times 10^{-1}$ \\
\hline 2 & 64.3 & $1.7 \times 10^{-1}$ \\
\hline
\end{tabular}

Temperature and Air Velocity Effects on Drying Time Duration

The fresh petals were dried in the air temperatures of 35,45 and $55^{\circ} \mathrm{C}$ and different air velocity levels $\left(0.4,1.2\right.$ and $\left.2 \mathrm{~m} \cdot \mathrm{s}^{-1}\right)$. Figure 2 shows the decreasing trend of moisture content percentage over time due to temperature and air velocity.
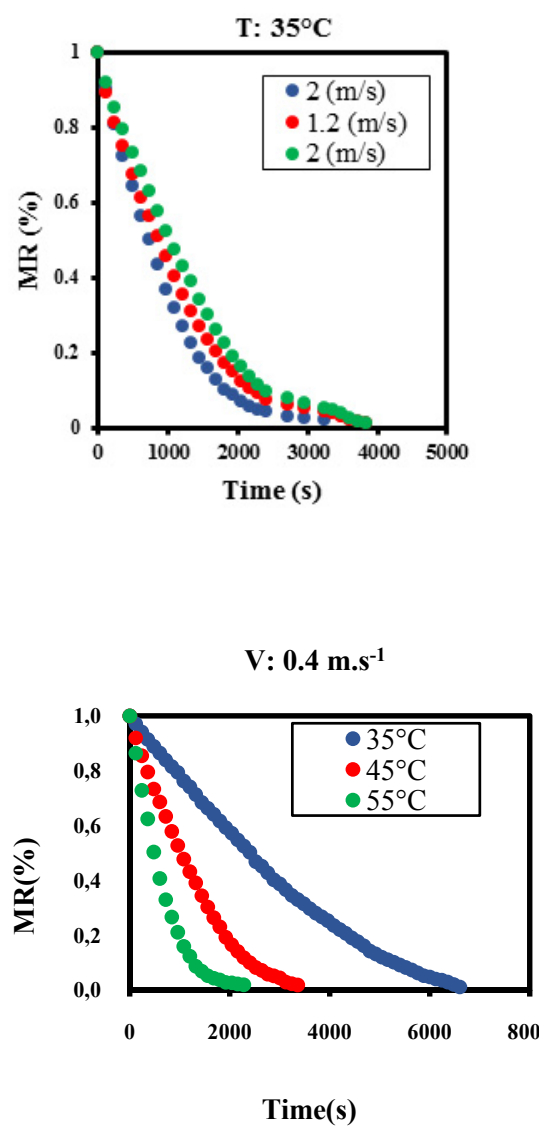
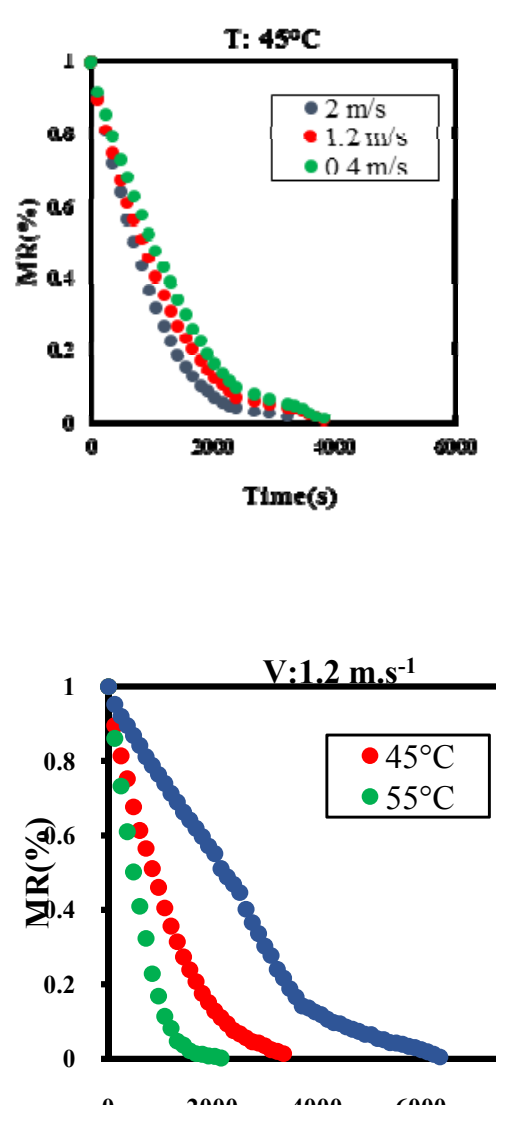
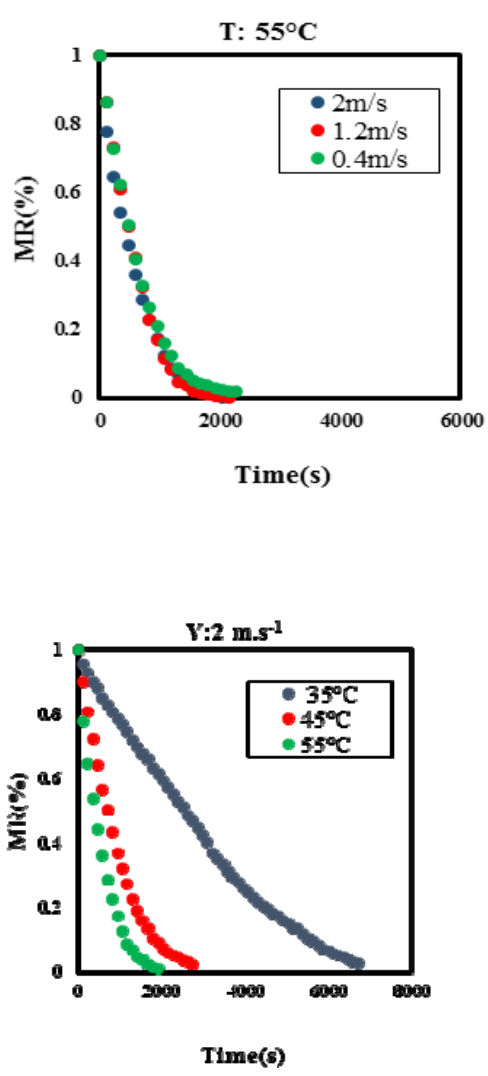

Figure 2 - Trend of variations of moisture content percentage with time for drying conditions

As shown in Table 4, the maximum (6720 s) and minimum (2040 s) drying times were at temperature of $35^{\circ} \mathrm{C}$ with air velocity of $0.4 \mathrm{~m} \cdot \mathrm{s}^{-1}$ and temperature of $55^{\circ} \mathrm{C}$ with air velocity of $2 \mathrm{~m} \cdot \mathrm{s}^{-1}$, respectively. Drying time durations were $2000-$ $7000 \mathrm{~s}$ at the 35,45 and $55^{\circ} \mathrm{C}$ air temperatures and $0.4,1.2$ and $2 \mathrm{~m} \cdot \mathrm{s}^{-1}$ air velocity levels. The longest drying time was 3.5 times higher than those of the 
shortest one. Figure 2 also demonstrates that the overall time of drying at $55^{\circ} \mathrm{C}$ was shorter than all the air velocities, suggesting that the temperature of drying was more effective than the air velocity. The increase in the temperature of drying increases the energy rate, the thermal gradient inside the product and also the accessible energy in the substrate for water transfer from the RDP. Therefore, higher temperatures lead to the faster drying rate and shorter drying time [26]. These results are similar to the findings of Kumar et al. [27] who dried different vegetables by the thin-layer dryer.

Table 4 - Time needed for removing moisture to $10 \%$ D.B. level for a combination of drying conditions

\begin{tabular}{|c|c|c|}
\hline $\begin{array}{c}\text { Temperature } \\
\left({ }^{\circ} \mathbf{C}\right)\end{array}$ & $\begin{array}{c}\text { Hot air velocity } \\
\left(\mathbf{m s}^{-1}\right)\end{array}$ & Time (s) \\
\hline \multirow{3}{*}{35} & 0.4 & 6720 \\
& 1.2 & 6600 \\
& 2 & 6480 \\
\hline \multirow{3}{*}{45} & 0.4 & 3360 \\
& 1.2 & 3240 \\
55 & 2 & 3240 \\
\hline & 0.4 & 2280 \\
& 1.2 & 2160 \\
& 2 & 2040 \\
\hline
\end{tabular}

Increasing the hot air velocity reduced the moisture content of the RDP, and hence enhanced the drying rate. At first, RDP bulk water can be easily transferred to the surface and evaporated. With increasing the time of drying a significant decrease in the moisture was observed (Fig. 1). The internal moisture transfer rate is constant and does not evaporate easily. Therefore, the drying time is decreased with the increase of air velocity [28].

Influence of the Temperature and Air Velocity on RPE Properties

Anthocyanins that are natural dyes and food coloring agents are generally present in fruits and vegetables. They have beneficial health effects and possess strong antioxidative and antimicrobial activities. The presences of anthocyanins in RPE as quercetin-3-O-glucoside, kaempferol-3-O- rhamnoside, and kaempferol-3-O-arabinoside have been reported by several researchers [29]. The antioxidative activities are affected by drying process such as air temperature and velocity [30].

In this study, the TAC was determined by the $\mathrm{pH}$-differential method. The anthocyanin content in RPE was $77-240 \mathrm{mg} \cdot \mathrm{L}^{-1}$ (as cyanidin-3-glucoside) (Table 5). Similar results were reported for Rosa damascena petals by Ginova et al. [31]. TAC was in the same range $\left(179-314 \mathrm{mg} \cdot \mathrm{L}^{-1}\right)$ that has been previously reported by Bayram et al. [18] for samples from seven industrial-scale plantations. TAC of extracts obtained from edible flowers (Poppy, Red tulip, Rose and Roselle) in the same study were found within the range of 10 to 405 $\mathrm{mg} \cdot \mathrm{kg}^{-1}$ dry extract. The TAC in the dried rose petals is more than fruits such as red grape (26.7 $\left.\mathrm{mg} \cdot \mathrm{L}^{-1}\right)$ and apple $\left(1.3-2.3 \mathrm{mg} \cdot \mathrm{L}^{-1}\right)$ and less than of red fruit juices such as Sweet cherry $\left(256.6 \mathrm{mg} \cdot \mathrm{L}^{-1}\right)$ Blackberry $\left(739.93 \mathrm{mg} \cdot \mathrm{L}^{-1}\right)$, Sour cherry (369.39 $\left.\mathrm{mg} \cdot \mathrm{L}^{-1}\right)$, Black currant $\left(1543.8 \mathrm{mg} \cdot \mathrm{L}^{-1}\right)$ and Chokeberry $\left(3042.2 \mathrm{mg} \cdot \mathrm{L}^{-1}\right)$ [32-33]. Our results show that the temperature had a significant impact on the TAC, the lower temperature caused the more TAC (Table 5). Increasing the air velocity from 0.4 to $1.2\left(\mathrm{~m} \cdot \mathrm{s}^{-1}\right)$, at the temperature of $45-55^{\circ} \mathrm{C}$, caused an increasing the amount of anthocyanins increased. However, at the air velocity of $1.2-2\left(\mathrm{~m} \cdot \mathrm{s}^{-1}\right)$, a decrease was observed showing that the air velocity at the $35^{\circ} \mathrm{C}$ did not have a significant impact on the total anthocyanin.

Antioxidant activity of RPE were examined by applying the 2,2-diphenyl-1-picrylhydrazyl (DPPH) radical scavenging method and FRAP assay. The methanol extracts showed higher DPPH (30.01 vs $59.51 \%$ ) scavenging power and lower FRAP (992.27 vs $\left.1213.24 \mu \mathrm{mol}\left(\mathrm{Fe}^{+2}\right) \cdot \mathrm{L}^{-1}\right)$ with increasing temperature from 35 to $55^{\circ} \mathrm{C}$ (Table 5). The DPPH depends on structural conformation, whereas FRAP assay is less sensitive toward hydrophilic antioxidants and the interaction of antioxidant compounds. Thus, DPPH may not show the accurate antioxidant capacity of compounds compared to the latter [34]. 
Table 5 - Effect of drying air temperature and velocity on total anthocyanin content (TAC) and antioxidant activity

\begin{tabular}{|c|c|c|c|c|c|}
\hline \multirow{2}{*}{ Temperature $\left({ }^{\circ} \mathbf{C}\right)$} & $\begin{array}{c}\text { Velocity of air } \\
\left(\mathbf{m s}^{-1}\right)\end{array}$ & $\begin{array}{c}\text { TAC (mg.c3g/L } \\
\text { of extract) }\end{array}$ & RSA (\%) & $\begin{array}{c}\text { Folin (mg of } \\
\text { GA/g of extract) }\end{array}$ & $\begin{array}{c}\text { FRAP }(\boldsymbol{\mu m o l} \\
\left.\left(\mathbf{F e}^{+2}\right) \mathbf{L}^{-1}\right)\end{array}$ \\
\hline \multirow{3}{*}{55} & 2 & $160.10 \pm 9.09 \mathrm{~b}$ & $59.51 \pm 1.96 \mathrm{a}$ & $661.33 \pm 2.11 \mathrm{a}$ & $992.27 \pm 12.47 \mathrm{~d}$ \\
\cline { 2 - 6 } & 1.2 & $180.59 \pm 4.76 \mathrm{~b}$ & $58.37 \pm 2.70 \mathrm{a}$ & $643.33 \pm 5.03 \mathrm{a}$ & $1001.78 \pm 4.11 \mathrm{c}$ \\
\cline { 2 - 6 } & 0.4 & $77.40 \pm 14.62 \mathrm{c}$ & $54.71 \pm 2.60 \mathrm{a}$ & $658.33 \pm 4.98 \mathrm{a}$ & $1119.39 \pm 8.19 \mathrm{~b}$ \\
\hline \multirow{3}{*}{45} & 2 & $135.06 \pm 8.78 \mathrm{c}$ & $31.97 \pm 11 \mathrm{~d}$ & $612.33 \pm 8.05 \mathrm{~b}$ & $837.24 \pm 7.53 \mathrm{~d}$ \\
\cline { 2 - 6 } & 1.2 & $239.02 \pm 9.07 \mathrm{a}$ & $34.77 \pm 0.66 \mathrm{~cd}$ & $618.33 \pm 6.66 \mathrm{~b}$ & $1006.53 \pm 7.58 \mathrm{c}$ \\
\cline { 2 - 6 } & 0.4 & $158.59 \pm 5.15 \mathrm{~b}$ & $52.08 \pm 1.75 \mathrm{ab}$ & $624 \pm 9.88 \mathrm{~b}$ & $1261.15 \pm 6.36 \mathrm{a}$ \\
\hline \multirow{3}{*}{35} & 2 & $223.08 \pm 9.83 \mathrm{a}$ & $43.69 \pm 1.16 \mathrm{bc}$ & $537.33 \pm 8.7 \mathrm{~d}$ & $1206.71 \pm 5.99 \mathrm{a}$ \\
\cline { 2 - 6 } & 1.2 & $220.05 \pm 9.47 \mathrm{a}$ & $44.26 \pm 2.68 \mathrm{bc}$ & $581.66 \pm 5.44 \mathrm{c}$ & $1092.06 \pm 3.41 \mathrm{~b}$ \\
\cline { 2 - 6 } & 0.4 & $229.91 \pm 8.20 \mathrm{a}$ & $30.01 \pm 1.21 \mathrm{~d}$ & $577.2 \pm 7.67 \mathrm{c}$ & $1213.24 \pm 10.22 \mathrm{a}$ \\
\hline
\end{tabular}

There is a positive relationship between total phenolic content and Radical scavenging capacity (DPPH); and some research have observed a high correlation. But some other researchers reported negative correlation between total phenolic content and antioxidant activity because total phenolic compounds do not contain all the antioxidants present in the extract [35].

\section{Acknowledgments}

The authors would like to thank the technical support by Department of Agricultural Engineering Institute, Khorasan Razavi Agricultural and Natural Resources Research and Education Center, AREEO, Mashhad/IRAN.

\section{References}

1. Mahboubi, M. Rosa damascene as holy ancient herb with novel applications// J. trad. Compl. Med. -2016. - 6. -P. 10-16.

2. Yang, L, Ren, J, Wang, Y. Chemical investigation of volatiles emitted from flowers of three varieties of Damask Rose cultivated in Beijing// Hort. Environ. Biotechnol. -2014. -55(6). P. 524-530.

3. Kazaz, S, Baydar, H, Erbas, S, Variations in Chemical Compositions of Rosa damascena Mill. and Rosa canina L. Fruits, Czech// J. Food Sci. 2009. - 27(3). -P. 178-184.

4. Baydar, H, Schulz, H, Kruger, H, Erbas, S, Kineci, S. Influences of fermentation time, hydrodistillatiotion time and fractions on essential oil composition of damask rose (Rosa Damascena Mill.)// J. Essent oil Bear Pl. -2008. - 11. - P. 224232.

Int. j. biol. chem. (Online)
5. Balladin, D.A, Headley, O. Solar drying of rose (Rosa sp.) petals// Renewable Energy. -1999. P. $-249-255$.

6. Haghighi, M, Tehranifar, A, Nikbakht, A, Kafi, M, Research and current profile of Iranian production of Damask Rose (Rosa Damascena Mill.), In: VIIIth Int. People- Plant Symp. Acta Hort. ISHS. -2008. -P. 251-254.

7. Brennan, J.G. Drying. Theory of air- drying. In: Encyclopedia of food sciences and nutrition, Caballero B, Trugo LC, Finglas PM (eds.), Academic Press, Elsevier Sci. Ltd., Oxford, UK// 2003. - P. -1913-1917.

8. Maskan, M. Drying, Shrinkage and rehydration characteristics of kiwi fruits during hot air and microwave drying// J. Food Eng. -2001. 48(2). - P.:177-182.

9. Bayhan, A.K, Boyar, S, Caglar, M.F, Akdeniz, R.C, Kayaalp, O. Design of the experimental dryer for medical \& aromatic plants// Hungarian Agri. Eng. -2011.- 23.- P. 5-8.

10. Aghbashlo, M, Kianmehr, MH, Akhijahani, HS. Modeling of thin-layer drying of potato slices in length of continuous band dryer// J. Energy Conv. Manage.-2009. -50.5. - P. 1348-1355.

11. Omid, M, Yadollahinia, A.R, Rafiee, S. A thin-layer drying model for paddy dryer. In the International conference on Innovations in Food and Bioprocess Technologies, 12th-14th December 2006, AIT, Pathumthani, Thailand.

12. Chaji, H, Hedayatizadeh, M. Quality assessment and kinetics of dehydrated watermelon seeds: Part 1.// Eng. in Agri. Environ. Food, -2017. 10. - P.178-185.

13. Doymaz, I., Sahin, M. Effect of temperature and pre-treatment on drying and rehydration characteristics of broccoli slices// J. of Food Meas. Charac. -2016. - 10(2). -P. 364-373. 
14. Nwajinka, C.O, Nwuba E.I.U, Udoye B.O. Moisture diffusivity and activation energy of drying of melon seeds// Int. J. App. Sci. Eng. -2014. - 2(2). -P. 37-43.

15. Rizvi, S.S.H. Thermodynamics of foods in dehydration, In Engineering Properties of Foods, M. A. Rao \& S. S. H. Rizvi (ads). -1986. Marcel Dekker. New York, P. 196.

16. Doymaz, I. Air-drying characteristics of tomatoes// J. Food Eng. -2007. - 78(4). -P.12911297.

17. Lee, J, Durst, R.W, Wrolstad, R.E. Determination of Total Monomeric Anthocyanin Pigment Content of Fruit Juices, Beverages, Natural Colorants, and Wines by the $\mathrm{pH}$ Differential Method: Collaborative Study// J. AOAC Inter. 2005. - 88(5). - P. 1269-1278.

18. Bayram, O, Sagdic, O, Ekici, L. Natural food colorants and bioactive extracts from some edible flowers// J. App. Bot. Food Qual. -2015. -88. P. 170 - 176.

19. Benzie, I, Strain, J. The Ferric reducing ability of plasma (FRAP) as a measure of antioxidant activity. The FRAP assay// Anal. Bioch. -1996. -189. - P. 70-76.

20. Singleton, V.L, Rossi, Jr J.A.Colorimetry of total phenolics with phosphomolybdic phosphotungstic acid reagents// Am. J. Enol. Viticul.-1965. - 16. -P.144-158.

21. Karimi Akandi, S.R, Bankar, A., Rosa Damascena Mill. Moisture modeling in hot air dryer using mathematic models and artificial neural network, Iran// J. Med. Arom. Pl. -2014. -30(2). - P. 250-259.

22. Arslan, D., Ozcan, M.M. Evaluation of drying methods with respect to drying kinetics, mineral content, and color characteristics of savory leaves // Food and bioprocess technology. - 2012. 5(3), P. 983-991.

23. Minaei, S, Motevali, A, Najafi, GH. H, Mousavi Seyedi, S.R. Influence of drying methods on activation energy, effective moisture diffusion and drying rate of pomegranate arils (Punica Granatum)// AJCS. -2011. - 6(4). -P.584-591.

24. Sharayei, P, Hedayatizadeh, M, Chaji H, Einafshar, S. Studying the thin-layer drying kinetics and qualitative characteristics of dehydrated saffron petals// J. of Food Proc. Preserv. -2018. - 42(2). P:1-9.
25. Amira, T, Saber, C, Fethizayrouba, K. Moisture diffusivity and shrinkage of fruit and cladode of ountice ficus-indica during infrared drying// J. food proc. -2014. - 1. P. 1-9.

26. Mohammad, Z, Seyed, H. S. Barat, G. Kinetic drying and mathematical modeling of Apple slices in dehydration process// J. food proc. tech.2013. - 4(7). - P. 1-4.

27. Kumar, N, Sarkar, B.C, Sharma H.K. Development and characterization of extruded product of carrot pomace, rice flour and pulse powder// Afr. J. Food Sci. -2010. -4. -P.703-17.

28. Nadi, F. Development of a New Model for Mass Transfer Kinetics of Petals of Echium amoenum Fisch. \& C.A. Mey. under Fluidized Bed Conditions// Food Technol. Biotechnol. -2016. 54(2). -P. 217-227.

29. Schieber, A, Mihalev, K, Berardini, N, Mollov, P, Carle, D. Flavonol Glycosides from Distilled Petals of Rosa damascene Mill., Zeitschrift für Naturforschung, 60(5-6):379-84 (2005).

30. López-Vidaña, E.C, Figueroa, I.P, Cortés, F.B, Rojano, B.A, Ocañ, A.N. Effect Of Temperature On Antioxidant Capacity During Drying Process Of Mortiño (Vaccinium meridionale Swartz)// Int. J. Food Prop. - 2016. - 20(2). - P. 294-305.

31. Ginova, A, Mihalev, K, Kondakova, V, Antioxidant Capacity of Petals and Leaves from Different Rose (Rosa damascene Mill.) Plantations in Bulgaria// Int. J. Pure \& App. Bios. -2013. - 1(2). P. 38-43.

32. Jakobek, L, Seruga, M, MedvidovicKosanovic, M, Novak, I. Anthocyanin content and antioxidant activity of various red fruit juices// Deut. Leb.-Rund. -2007. -103(2). -P:58-64.

33. Wu, X, Beecher, G.R, Holden, J.M, Hytowitz, D.B, Gebhardt, S.E, Prior, R.L. Concentrations of Anthocyanins in Common Foods in the United States and Estimation of Normal Consumption// J. Agric. Food Chem. -2006. -54. -P. 4069-4075.

34. Kaur, T.C, and Kapoor, H.C. Antioxidant in fruits and vegetable-The millennium's health// Intl. J. Food Sci. Technol. -2001. - 36. P.703-725.

35. Tawaha, K, Alali, F.Q, Gharaibeh,M, Mohammad, M, and El-Elimat, T. Antioxidant activity and total phenolic content of selected Jordanian plant species// Food Chem. -2007. -104. P.1372-1378. 